\title{
First Commercial Semen Cryopreservation and Main Spermatological Features of Anatolian Buffalo
}

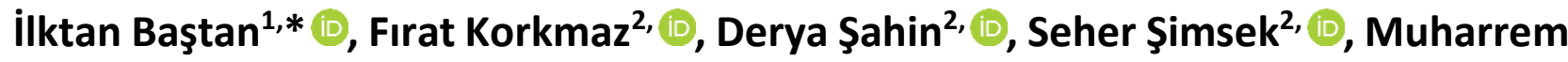 \\ Satılmış, \\ ${ }^{1}$ Genetics and Embryo Technologies Application and Research Center, Mehmet Akif Ersoy University, Burdur, Turkey \\ ${ }^{2}$ International Center for Livestock Research and Training, Department of Biotechnology, Ankara, Turkey \\ ${ }^{3}$ Bakırçay University, Menemen Vocational School, Izmir, Turkey \\ *Corresponding author
}

\section{Article History \\ Received: 03 May 2021 \\ Accepted: 26 Jul 2021}

First Online: 20 Sep 2021

\section{Corresponding Author \\ E-mail: ilktan@outlook.com}

\author{
Keywords \\ Artificial insemination \\ Bubalus bubalis \\ CASA \\ Frozen semen \\ Mediterranean buffalo
}

\begin{abstract}
Conventional buffalo semen freezing studies are limited in Anatolian buffaloes, which are overly sensitive to exogenous stimulation. The present study's object was to determine the main features of Anatolian Buffalo semen obtained by artificial vagina method for the first time. A total number of 150 ejaculates were collected from three Anatolian Buffalo bulls (app. 4 years of age). The mean pH, volume and concentration of semen were found $6.63 \pm 0.15,1.61 \pm 0.5 \mathrm{ml}, 1629 \pm 222.67 \times 10^{6}$ spermatozoa $/ \mathrm{ml}$, respectively. The sperm motion characteristics were determined by using a computerassisted sperm analysis system (CASA); the total and progressively motile sperm values were $57.12 \pm 5.63 \%, 23.22 \pm 4.47 \%$ and other kinetic parameters such VAP, VSL, VCL, ALH, BCF, STR, LIN were found $94.71 \pm 8.48 \mu \mathrm{m} / \mathrm{s}, 72.6 \pm 7.08 \mu \mathrm{m} / \mathrm{s}, 160.9 \pm 15.66 \mu \mathrm{m} / \mathrm{s}, 7.8 \pm 3.75$ $\mu \mathrm{m}, 29.15 \pm 1.56 \mathrm{~Hz}, 76.91 \pm 3.87 \%, 46.21 \pm 2.61 \%$, respectively after thawing. Among buffalo bulls, differences in semen $\mathrm{pH}$ values were statistically significant $(\mathrm{P}<0.05)$, while differences in ejaculate volume, semen concentration, total motility, progressive motility, VAP, VSL, VCL, ALH, BCF, STR, and LIN were not ( $P>0.05)$. As a result, frozen Anatolian buffalo semen can be obtained economically and can be used for animal breeding in assisted reproductive biotechnology such as artificial insemination or in vitro embryo production commercially.
\end{abstract}

\section{Introduction}

Domestic water buffaloes are studied under two classes as river (Bubalus bubalis) and swamp buffaloes (Bubalus carabenensis). Despite of, one breed comprises swamp buffaloes, there are many breeds such as Murrah, Nilli-Ravi, Kündi, Surti, Jafarabadi, Nagpuri, Pandharpuri and Mediterranean buffalo in river buffaloes (Kelgokmen, 2015). Anatolian water buffalo (as shown in Figure 1) located in Turkey originated from the Mediterranean subgroup of river buffaloes (Soysal et al., 2007). Although Turkey had a high population of Anatolia buffalo earlier in this century, the buffalo population had fallen below 100 thousand head in 2010 (Atasever et al., 2008; Aköz et al., 2017; Çolak et al., 2017). Thus, genetic materials (DNA, somatic cell) of Anatolian buffalo against the danger of extinction; have been stored in the national gene bank of Turkey (Arat, 2011).

Sperm cryopreservation forms the basis of gene banks with its ease of method, success in its transfer to the field, economical storage and alternative fertilization application options. Besides, the use of frozen semen by artificial insemination is the most common biotechnological practice that enables rapid and inexpensive genetic progress in many animal species for increasing yield and product quality (Morrell, 2011).

The first buffalo sperm cryopreservation in the world was carried out in the 1950s (Roy et al., 1956). In this sense, conventional cryopreservation of sperm with different buffalo species is a method that has been used for a long time (Andrabi, 2009). Until recently, artificial inseminations in Anatolian buffaloes were generally performed with Mediterranean buffalo semen that 
imported from Italy. Because of there was no frozen Anatolian buffalo semen for commercial purposes (Aköz et al., 2017). Due to the high prices of imported frozen buffalo semen, breeders in Turkey prefer natural breeding rather than artificial insemination (Isık, 2015; Yılmaz, 2013; Okuyucu et al., 2018). For these reasons, the National Anatolian Buffalo Breeding Project, coordinated and supported by the General Directorate of Agricultural Research and Policies (TAGEM) was initiated in 2010. As an outcome of this leap sperm production from Anatolian buffalo bulls, with its superior genomic characterization and acceleration of breeding activities by artificial insemination, is one of TAGEM's priority strategic plans (Soysal et al., 2020). For these reasons, the first commercial Anatolian buffalo sperm production was started at the Lalahan International Livestock Research and Training Center, Ankara.

Cryopreservation of epididymal Anatolian buffalo sperm has been studied, and valuable data have obtained (Selcuk et al., 2015; Yeni et al., 2017). However, collection process was not performed with artificial vagina. It is revealed that it is not suitable for commercial production and it is necessary to conduct new studies with common methods due to its effects on ejaculate's quality.

In the present study, unlike the studies mentioned above, it was the first time to use a controlled semen collection system (Lalahan Model) in terms of occupational safety and animal welfare for semen collection from Anatolian buffaloes which are overly sensitive to exogenous stimulation (Korkmaz et al., 2019; Baştan, 2020). For this purpose, a novel collection system was used and semen characteristics of frozen Anatolian buffalo semen collected by artificial vagina were investigated after freezing.

\section{Materials and Methods}

\section{Animals}

In this study, three Anatolian Buffalo bulls (apr. 4 years of age) were used at the Lalahan International Center for Livestock Research and Training (Ankara,

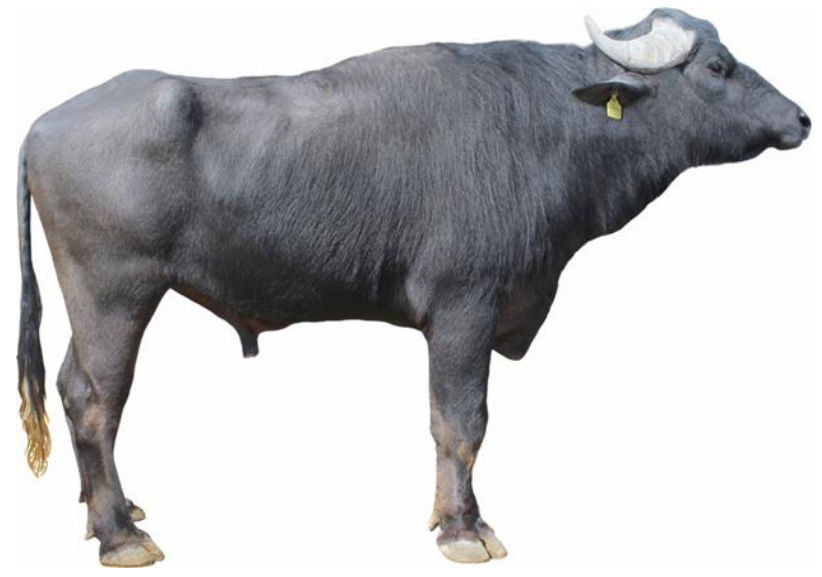

Figure 1. Anatolian buffalo bull.
Turkey), and maintained under uniform feeding and housing conditions that individually in pens.

\section{Preparation of Artificial Vagina}

Semen was collected using a bovine artificial vagina with soft neoprene liner (AV; $30 \mathrm{~cm}$ long; $5 \mathrm{~cm}$ internal diameter; IMV, France). The internal temperature of the artificial vagina was maintained $40 \mathrm{oC}$. In order to lubricant, the contact of bull penis with the soft neoprene liner of the $\mathrm{AV}$, the inner surface of the liner was covered with a thin layer of sterile petroleum jelly (Vaseline ${ }^{\circledR}$ ). Sterile glass conical cylindrical 15-ml collection tube, which used to collect semen and transporting it to the laboratory was placed at the end of artificial vagina. The protective felt cover was used to keep the artificial vagina and collection tube at the correct temperature during the collection process and prevent semen thermal shock after the bull ejaculation (Ansari et al., 2017; Baştan 2018).

\section{Semen Collection}

In terms of occupational safety and animal welfare, a controlled semen collection model (Lalahan model) was used to collect semen from Anatolian buffalo bulls (as shown in Figure 2). In this way, each bull came to the semen collection arena from its individual pen without a bull handling person. A female Anatolian buffalo was used as a teaser animal to steer male buffaloes. A total number of 150 ejaculates were collected by using the Lalahan Model with the aid of an artificial vagina twice a week during 30 weeks (Korkmaz et al., 2019; Baştan, 2020).

\section{Determination of Semen Volume, Concentration and $\mathrm{pH}$}

The volume of ejaculates was measured in a conical tube graduated at $0.1 \mathrm{ml}$ intervals, and sperm concentration was determined by using the Accucell photometer (IMV, L'Aigle, France). The $\mathrm{pH}$ of semen samples was determined by indicator paper strips and digital pH meter simultaneously (Hanna-Hi 221, Smithfield, RI) (Khawaskar et al., 2012).

\section{Semen Freezing Processing}

A soybean-based semen extender (Andromed, Minitüb, Germany) was used for diluting ejaculates with $>80$ total motile sperm to a final concentration of $100 \times 10^{6}$ spermatozoa/ml. Samples were cooled at $+4^{\circ} \mathrm{C}$ for 3 hours. Afterwards, they were packaged in $0.25 \mathrm{ml}$ French straws (IMV, L'Aigle, France) by using an automatic straw filling and sealing machine (MX4, IMV, L'Aigle, France). The straws were frozen to $-140^{\circ} \mathrm{C}$ $\left(-3^{\circ} \mathrm{C} / \mathrm{min}\right.$ from +4 to $-10^{\circ} \mathrm{C} ;-40^{\circ} \mathrm{C} / \mathrm{min}$ from 10 to 100 ${ }^{\circ} \mathrm{C}$; $-20{ }^{\circ} \mathrm{C} / \mathrm{min}$ from -100 to $-140{ }^{\circ} \mathrm{C}$ ) by using an automatic freezing machine (Digital cool 5300ZB 250, IMV, L'Aigle, France), plunged into liquid nitrogen and 
stored at $-196^{\circ} \mathrm{C}$ (Tuncer et al., 2010; Ansari et al., 2017).

\section{Thawing and Post-Thaw Evaluation}

After one month of storage period at $-196{ }^{\circ} \mathrm{C}$, the straws were thawed in a water bath $\left(37^{\circ} \mathrm{C}, 30 \mathrm{~s}\right)$ for post-thaw kinetics analysis. Afterwards, a $3 \mu \mathrm{l}$ sample of semen was put onto a prewarmed four chamber slide (20 $\mu \mathrm{m}$, Leja slides, IMV, L'Aigle, France) and sperm kinetics parameters were determined by using computer-assisted sperm analysis system, as shown in Figure 3 (CASA; IVOS I, Hamilton Thorne Inc., Beverly, USA). CASA was set up as follows: frame rate $60 \mathrm{~Hz}$; minimum contrast 80 ; low and high intensity gates 0.30 1.70; low and high static size gates $0.10-3.40$; low and high elongation gates 8-97; default cell size 5 pixels; default cell intensity 70 . In the analysis settings, spermatozoa with VSL $70 \%$ and VAP $50 \mu \mathrm{m} / \mathrm{s}$ were evaluated as progressively motile. The motility parameters were expressed in percentage units. Other kinematics average path velocity (VAP, $\mu \mathrm{m} s-1)$, straight line velocity (VSL, $\mu \mathrm{m} s-1)$, curvilinear velocity $(\mathrm{VCL}, \mu \mathrm{m}$ s-1), straightness (STR = [VSL/VAP] $\times 100)$, linearity (LIN $=[\mathrm{VSL} / \mathrm{VCL}] \times 100)$, beat-cross frequency $(\mathrm{BCF}, \mathrm{Hz})$, amplitude of lateral head displacement $(A L H, \mu m)$ were also evaluated and expressed with their own units (Tuncer et al., 2010; Sahin et al., 2020).

\section{Statistical Analysis}

For statistical analyses, data were examined with Shapiro-Wilk test for normality and with Levene test for homogenity of variances as parametric test assumptions. The statistical control of the difference between the variables was done with ANOVA. The Tukey test used to evaluation of differences between the buffalo bulls. Descriptive statistics for each variable were calculated and presented as mean \pm standard error (Mean \pm SE). All statistical analyzes were examined using the SPSS ${ }^{\circledR} 22.0$ package program and $\mathrm{P}<0.05$ level was considered significant.

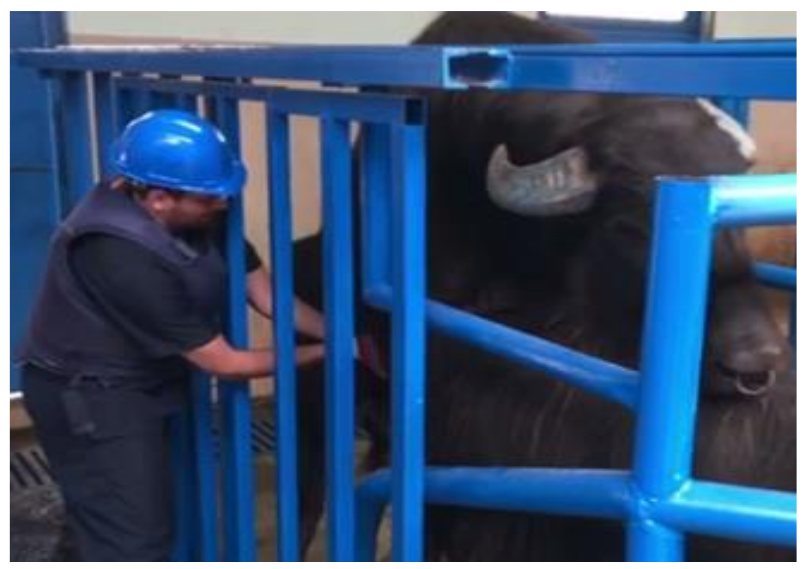

Figure 2. Semen collection by Lalahan Model in Anatolian buffalo bull.

\section{Results}

The present study aimed to describe some sperm characteristics and spermatological parameters of Anatolian Buffalo sperm. In particular, the data important for Al stations and parameters that routinely used by andrology laboratories were prioritized. The data $\mathrm{pH}$, volume, concentration of semen, total motility and progressive motility were given Table 1 . The mean $\mathrm{pH}$, volume, concentration of semen, total motility and progressive motility were found $6.63 \pm 0.15,1.61 \pm 0.5$ $\mathrm{ml}, 1629 \pm 222.67 \times 10^{6}$ spermatozoa/ml, 57.12 $\pm 5.63 \%$, $23.22 \pm 4.47 \%$ respectively after thawing.

The sperm kinetic values (VAP, VSL, VCL, ALH, BCF, STR, LIN) were given Table 2. The mean VAP, VSL, VCL, $A L H, B C F$, STR and LIN were found $94.71 \pm 8.48 \mu \mathrm{m} / \mathrm{s}$, $72.6 \pm 7.08 \mu \mathrm{m} / \mathrm{s}, 160.9 \pm 15.66 \mu \mathrm{m} / \mathrm{s}, 7.8 \pm 3.75 \mu \mathrm{m}$, $29.15 \pm 1.56 \mathrm{~Hz}, 76.91 \pm 3.87 \%, \quad 46.21 \pm 2.61 \%$, respectively after thawing. While the $\mathrm{pH}$ values are statistically significant among the bulls $(P<0.05)$, differences in terms of other spermatological and CASA parameters (ejaculate volume, sperm concentration, total motility, progressive motility, VAP, VSL, VCL, ALH, $B C F, S T R, L I N)$ were not significant $(P>0.05)$.

\section{Discussion}

According to this study, the mean semen volume of the Anatolian buffalo was determined as $1.61 \pm 0.5 \mathrm{ml}$. When compared to domestic buffalo breeds such as Murrah, Surti, Jafarabadi, Nili Ravi, Kundihi and swamp buffaloes $(2.58 \mathrm{ml}, 3.16 \pm 0.76 \mathrm{ml}, 4.720 .24 \mathrm{ml}$, $2.80 \pm 1.62 \mathrm{ml}, 2.25 \pm 0.01 \mathrm{ml}, 2.9 \mathrm{ml}$, respectively), it can be evaluated that the volume of semen obtained in Anatolian buffalo ejaculation is lower than other breeds (Malik et al., 1974; Jainudeen et al., 1982; Dhami et al., 2005; Bhakat et al., 2011; Kaka et al., 2012; Khawaskar et al., 2012).

The sperm concentration of the Anatolian buffalo, another parameter obtained in the study, was

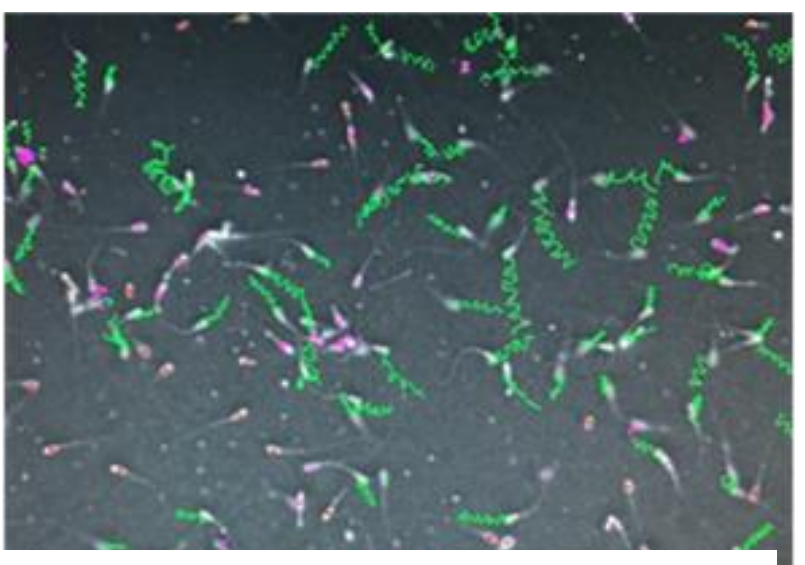

Figure 3. Assessment of motion and kinematic characteristics of semen using computer-assisted semen analysis (CASA).

Yellow color: Progressive motile sperm, Pink color: Motile sperm, Red color: Immotil sperm. 
determined as $1629 \pm 222.67 \times 10^{6} \mathrm{sperm} / \mathrm{ml}$. This value is in other domestic buffalo breeds; $990.65 \pm 143.9 \times 10^{6} \mathrm{sperm} / \mathrm{ml}$ in Mediterranean buffaloes, $998.91 \times 10^{6} \mathrm{sperm} / \mathrm{ml}$ in Murrah breed, $885.42 \pm 24.9 \times 10^{6} \mathrm{sperm} / \mathrm{ml}$ in Surti breed, $838.30 \pm 25.74 \times 10^{6} \mathrm{sperm} / \mathrm{ml}$ in Jafarabadi buffaloes. It has been reported that $1000 \pm 50.0 \times 10^{6} \mathrm{sperm} / \mathrm{ml}$ in Nili ravi, $1542 \pm 9.20 \times 10^{6} \mathrm{sperm} / \mathrm{ml}$ in Kundhi, and for Swamp buffalo $1006 \times 10^{6} \mathrm{sperm} / \mathrm{ml}$. As a matter of fact, although Anatolian buffalo semen volume was found low compared to other domestic buffalo breeds, it is observed that the concentration of spermatozoa is higher (Malik et al., 1974; Jainudeen et al., 1982; Galli et al., 1993; Bhakat et al., 2011; Ghodasara et al., 2018; Kaka et al., 2012; Khawaskar et al., 2012).

In the study, the semen $\mathrm{pH}$ value was determined as $6.63 \pm 0.15$. This value varies between 6.10 and 6.92 (Murrah; 6.92, Surti; 6.89 \pm 0.16 , Nili-Ravi 6.55 \pm 0.50 , Kundhi; $6.10 \pm 0.007$ ) in some domestic buffalo breeds. The semen characteristics of a bull in frozen semen production are important for extender optimization before freezing. In this process, post-thaw sperm concentration and production efficiency are evaluated according to the variables specified. Nevertheless, sperm characteristics such as semen volume, concentration, and $\mathrm{pH}$ may in a large variation specific to the breed, as well as they may vary depending on factors such as age, climate, number of false mounting and ejaculation frequency (Khawaskar et al., 2012;
Murphy et al., 2018; Sankhi et al., 2019; Şahin et al., 2020).

Computer aided sperm analysis systems (CASA), which reveal in vitro spermatozoon morphology and kinetic parameters in a detailed and systematic manner, are an analysis technique widely used in andrology laboratories. For validating the commercial license of frozen buffalo semen in Turkey, it must have at least $40 \%$ total motility and 15 million motile spermatozoa after thawing basically, according to Republic of Turkey Ministry of Agriculture and Forestry. Hence, the percentages of total motile and progressive motile spermatozoa are important among the sperm kinematic parameters in the evaluation of sperm quality. There are many studies indicating the correlation of these parameters with conception rates (Mahmoud et al., 2013; Inanc et al., 2018; Vincent et al., 2018). In this context, kinematic parameters determined by CASA analysis are presented in Table 1 and 2. Considering the parameters obtained from samples that were frozen with a soy lecithin-based plant-derived extender (AndroMed $\left.{ }^{\circledR}\right)$, it would be more accurate to compare the results with studies using similar extenders. Ansari et al. (2017) and Singh et al. (2018) determined the total motility values in the sperm cryopreservation studies performed with the same extender in Nili Ravi and Murrah buffaloes as $49.2 \pm 1.7 \%$ and $38.3 \pm 2.3 \%$ at post-thaw evaluation. The progressive motility value in Murrah buffaloes with the same extender was determined as $22.3 \pm 1.8 \%$ at postthaw. Compared with the total motility and progressive

Table 1. The Anatolian Buffalo semen characteristic and post-thaw motility parameters.

\begin{tabular}{lllllll}
\hline Parameters & $\begin{array}{l}\text { Buffalo Bull } \\
\text { No: } \mathbf{1}(\mathbf{n}=\mathbf{4 0})\end{array}$ & $\begin{array}{l}\text { Buffalo Bull } \\
\text { No: } \mathbf{2}(\mathbf{n}=50)\end{array}$ & $\begin{array}{l}\text { Buffalo Bull } \\
\text { No:3 }(\mathbf{n}=60)\end{array}$ & Mean \pm SE & Range & P-Value \\
\hline $\begin{array}{l}\text { Ejaculate Volume } \\
\text { (ml) }\end{array}$ & $1.75 \pm 0.52$ & $1.60 \pm 0.55$ & $1.55 \pm 0.44$ & $1.61 \pm 0.5$ & $0.2-4.1$ & $\mathrm{P}=0.545$ \\
$\begin{array}{l}\text { Concentration } \\
\left(\mathbf{1} \mathbf{1 0}^{6} \text { sperm/ml) }\right.\end{array}$ & $1589 \pm 254.65$ & $1622 \pm 227.84$ & $1683 \pm 189.86$ & $1629 \pm 222.67$ & $625-2678$ & $\mathrm{P}=0.352$ \\
$\mathbf{p H}$ & $6.65 \pm 0.17^{\mathrm{a}}$ & $6.62 \pm 0.13^{\mathrm{ab}}$ & $6.61 \pm 0.11^{\mathrm{b}}$ & $6.63 \pm 0.15$ & $6.45-6.72$ & $\mathrm{P}<0.05$ \\
$\begin{array}{l}\text { Total Motility (\%) } \\
\text { Progressive }\end{array}$ & $56.74 \pm 6.45$ & $56.66 \pm 5.11$ & $57.81 \pm 5.29$ & $57.12 \pm 5.63$ & $48-76$ & $\mathrm{P}=0.808$ \\
Motility (\%) & $23.25 \pm 4.24$ & $23.49 \pm 4.8$ & $22.92 \pm 4.25$ & $23.22 \pm 4.47$ & $16-35$ & $\mathrm{P}=0.931$ \\
\hline
\end{tabular}

$a, b$ : Different letters on the same line for each parameter represent a statistically significant difference $(P<0.05)$.

Table 2. The Anatolian Buffalo sperm kinetics parameters.

\begin{tabular}{|c|c|c|c|c|c|c|}
\hline Parameters & $\begin{array}{l}\text { Buffalo Bull } \\
\text { No: } 1(n=40)\end{array}$ & $\begin{array}{l}\text { Buffalo Bull } \\
\text { No: } 2(n=50)\end{array}$ & $\begin{array}{l}\text { Buffalo Bull } \\
\text { No: No: } 3 \\
(n=60)\end{array}$ & Mean \pm SE & Range & P-Value \\
\hline VAP ( $\mu \mathrm{m} / \mathrm{sec})$ & $94.94 \pm 9$ & $94.25 \pm 8.5$ & $94.97 \pm 7.97$ & $94.71 \pm 8.48$ & $79.9-137.8$ & $P=0.963$ \\
\hline VSL ( $\mu \mathrm{m} / \mathrm{sec})$ & $73.58 \pm 6.44$ & $71.49 \pm 8.35$ & $72.91 \pm 6.03$ & $72.6 \pm 7.08$ & $60.5-103.6$ & $P=0.706$ \\
\hline VCL ( $\mu \mathrm{m} / \mathrm{sec})$ & $161.74 \pm 15.21$ & $158.44 \pm 17.66$ & $162.57 \pm 13.59$ & $160.9 \pm 15.66$ & $125.8-207.8$ & $P=0.723$ \\
\hline ALH $(\mu \mathrm{m})$ & $7.24 \pm 0.44$ & $8.81 \pm 6.22$ & $7.24 \pm 0.38$ & $7.8 \pm 3.75$ & $5.9-8.6$ & $P=0.397$ \\
\hline $\mathrm{BCF}(\mathrm{Hz})$ & $29.36 \pm 1.3$ & $29.45 \pm 1.93$ & $28.71 \pm 1.26$ & $29.15 \pm 1.56$ & $25.7-32.6$ & $P=0.330$ \\
\hline STR (\%) & $77.87 \pm 2.4$ & $76.16 \pm 5.61$ & $76.9 \pm 2.36$ & $76.91 \pm 3.87$ & $68-84$ & $P=0.489$ \\
\hline LIN (\%) & $46.82 \pm 2.15$ & $45.82 \pm 3.35$ & $46.13 \pm 2$ & $46.21 \pm 2.61$ & $43-55$ & $P=0.578$ \\
\hline
\end{tabular}


motility $(57.12 \pm 5.63 \%$ and $23.22 \pm 4.47 \%)$ values obtained in this study, it can be expressed that the first Anatolian buffalo sperm cryopreservation trial was successful and its cryotolerance was higher when compared with other breeds. To clarify, in some domestic buffalo breeds were frozen with different extenders, the total motility values were between $37.92 \%$ and $67.84 \% \quad(37.92 \pm 1.12 \%, 49.3 \pm 12.8 \%$, $43.25 \pm 3.40 \%, 57.41 \pm 0.92 \%)$, and the progressive motility values vary between $20.4 \%$ and $30.64 \%$ (Kaka et al., 2012; Gaviraghi et al., 2013; Kumar et al., 2016; Singh et al., 2017; Ahmed et al., 2020; Pathak et al., 2020).

Singh et al. (2017), studied on Murrah buffaloes, and stated that VAP, VSL, VCL, kinematic values and ALH values were higher in buffaloes showing high fertility characteristics than buffaloes showing low fertility characteristics. He also stated that BCF, STR and LIN values were lower in buffaloes with high fertility characteristics. It has been reported that high motility does not only play a role in determining fertility, but also other sperm kinematics such as swimming pattern and sperm head movements play crucial roles also (Singh et al., 2017). The data obtained from this study are similar to the values stated in previous studies conducted on different domestic river buffalo breeds (Gaviraghi et al., 2013; Kumar et al., 20

16; Singh et al., 2017; Singh et al., 2018). Preliminary field studies (not statistically sufficient at the moment) were also carried out which pregnancy was obtained with Anatolian buffalo semen.

In conclusion, Anatolian buffalo semen collected by artificial vagina and frozen commercially with the evaluation of some spermatologically parameters (prefreeze and after thawing), non-return rates for the first time with this study. However, further studies are needed in order to determine Anatolian Buffalo sperm characteristics in a large sample count and field studies.

\section{References}

Ahmed, A., Ayaz, M., Mughal, D.H., Rehman, A., Mushtaq, M.H., Yousaf, M.S., Riaz, A. (2020). Anti-oxidative effect of I-lysine on post thaw quality of Nili-Ravi buffalo bull semen (Bubalus bubalis). Journal of Animal and Plant Sciences, 30:612-618. https://doi.org/10.36899 /JAPS.2020.3.0072

Aköz, M., Arik, D., Kul, M., Çelik, B. (2017). Buffalo breeding: Buffalo breeding in Turkey from past to today. Journal of Scientific and Technological Research, 3: 2422-8702.

Andrabi, S.M.H. (2009). Factors affecting the quality of cryopreserved buffalo (Bubalis bubalis) bull spermatozoa. Reproduction in Domestic Animals, 44: 552-569. https://doi.org/10.1111/j.14390531.2008.01240.x.

Ansari, M.S., Rakha, B.A., Akhter S. (2017). Cryopreservation of Nili-Ravi buffalo (Bubalus bubalis) semen in AndroMed $^{\circledR}$ extender; in vitro and in vivo evaluation. Reproduction in Domestic Animals, 52: 992-997. https://doi.org/10.1111/rda.13008.
Arat, S. (2011). In vitro conservation and preliminary molecular identification of some Turkish domestic animal genetic resources (TURKHAYGEN-I). In Proceedings of the 8th Global Conference on the Conservation of Animal Genetic Resources, Turkey. p.51-58.

Atasever, S., Erdem, H. (2008). Water buffalo raising and its future in Turkey. Anadolu Journal of Agricultural Sciences, 23(1): 59-64.

Baştan, I., Korkmaz, F., Şahin, D., Yırtıcı, S., Kinet, H., Satılmış, M., Tekerli, M. (2018). First commercial production and application of cryopreserved anatolian buffalo sperm. In Proceedings of the 9th National Reproduction and Artificial Insemination Science Congress, Turkey. p:126127.

Baştan, i. (2020). Controlled semen collection system for artificial insemination from Anatolian buffaloes. Turkish Patent and Trademark Office. Application Number of Patent: 2020/11130.

Bhakat, M., Mohanty, T.K., Raina, V.S., Gupta, A.K., Khan, H.M. (2011). Frozen semen production performance of Murrah buffalo bulls. Buffalo Bulletin. 30: 157-164.

Çolak, M., Javorka, L. (2017). Hungarian Expert Oszkár Wellmann's Report in the Establishment Years of the Republic of Turkey. 1st ed. p.115-155.

Dhami, A.J., Shelke, V.B. (2005). Investigations into the causes of poor semen quality and freezability in Jafarabadi buffalo bulls. The Indian Journal of Animal Sciences. 75: 925-929.

Galli, A., Bornaghi, V., Balduzzi, D., Buttazzoni, L., Aleandri, R. (1993). Sexual behaviour and semen quality relating to Italian Buffalo. Proceedings 3rd World Buffalo Congress, Varna, Bulgaria. pp.562-570.

Gaviraghi, A., Puglisi, R., Balduzzi, D., Severgnini, A., Bornaghi, V., Bongioni, G., Galli, A. (2013). Minimum number of spermatozoa per dose in Mediterranean Italian buffalo (Bubalus bubalis) using sexed frozen semen and conventional artificial insemination. Theriogenology, 79(8),1171-1176. https://doi:/10.1016/ j.theriogenology.2013.02.014.

Ghodasara, S.N., Gajbhiye, P.U., Ahlawat, A.R., Murthy, K.S. (2018). Evaluation of fresh semen quality and predicting the number of frozen semen doses in Jaffrabadi buffalo bull. Buffalo Bulletin. 35(1): 65-72.

Işık, M. (2015). Economic analysis of water buffalo farming in Mus province, Turkey. M.Sc. Süleyman Demirel University Isparta, Turkey.

İnanç, M,E., Çil, B., Tekin, K., Alemdar, H., Daşkin, A. (2018). The combination of CASA kinetic parameters and fluorescein staining as a fertility tool in cryopreserved bull semen. Turkish Journal of Veterinary and Animal Sciences. 42: 452-458. https://doi:10.3906/vet-1801-83.

Jainudeen, M.R., Bongso, T.A., Dass, S. (1982). Semen characteristics of the swamp buffalo (Bubalus bubalis). Animal Reproduction Science. 4: 213-217. https://doi:10.1016/0378-4320(82)90005-7.

Kaka, A., Samo, U., Rahoo, T.H., Rehman, Z.U., Shah, Z., Mushtag, M., Behan, A.A. (2012). Study on post thawing quality of Kundhi buffalo semen. Journal of Animal and Plant Sciences. 22(2 Supplement), 59-62.

Kelgökmen, i. (2015). Some morphometric traits of Anatolian Buffaloes. Livestock Studies. 55: 50-55.

Khawaskar, M.V., Panchal, M.T., Dhami, A.J., Hadiya, K.K., Patel, S.B. (2012). Seasonal variation in seminal biochemical constituents in Surti buffalo bulls. Indian Journal of Animal Reproduction, 33: 41-46. 
Korkmaz, F., Baştan, İ., Şahin, D., Yırtıcı, S. (2019). Lalahan model in commercial Anatolian buffalo semen production. Proceedings 12th World Buffalo Congress, İstanbul, Turkey. p.44.

Kumar, D., Kumar, P., Yadav, P.S. (2016). Quantitative evaluation of buffalo semen by CASA during cryopreservation process. The Indian Journal of Animal Reproduction. 37: 15-18.

Mahmoud, K.G.M., El Sokary, A.A.E., Abou El Roos, M.E.A., Nawito, M. (2013). Sperm characteristics in cryopreserved buffalo bull semen and field fertility. Iranian Journal of Applied Animal Science. 3: 777-783.

Malik, M,A., Ahmad, M., Gilani, H., Chaudhry, R.A. (1974). Studies on the morphology and abnormalities of buffalo spermatozoa. Pakistan Journal of Agricultural Research. 11: 41-46.

Morrell, J.M. (2011). Artificial insemination: current and future trends. In: Manafi M (editor). Artificial Insemination In Farm Animals. Rijeka, Croatia. p.1-14.

Murphy, E.M., Kelly, A.K., O’Meara, C., Eivers, B., Lonergan, P., Fair, S. (2018). Influence of bull age, ejaculate number, and season of collection on semen production and sperm motility parameters in Holstein Friesian bulls in a commercial artificial insemination centre. Journal of Animal Science, 96: 2408-2418. https://doi: /10.1093/jas/sky130.

Okuyucu, I.C., Bayyurt, L., Akdağ, A., Trink, C., Bulu, A. (2018). Evaluation of enterprises raising water buffalo in Samsun province of Turkey. International Journal of Scientific and Technological Research, 4(8): 1-5.

Pathak, P.K., Dhami, A.J., Chaudhari, D.V., Hadiya, K.K. (2020). Comparative evaluation of motility and kinematics of fresh versus frozen-thawed spermatozoa of cattle and buffalo bull by CASA. Indian Journal of Animal Research, 54: 1188-1194.

Roy, A., Srivastava, R.K., Pandey, M.D. (1956). Deep freezing of buffalo semen diluted and preserved in glycine - egg yolk medium. Indian Journal of Dairy Science, 9: 61-62.

Sankhi, S., Sapkota, K.R., Regmi, B. (2019). Effect of age and frequency of collection on quality of Jersey bulls semen at National Livestock Breeding Center (NLBC), Nepal. International Journal of Applied Sciences and Biotechnology, 7: 88-95. https//doi: /10.3126/ijasbt.v7i1.23312.
Selcuk, M., Akal, E. (2015). Testicular morphology and in vitro evaluation of frozen epididymal sperm of Anatolian buffalo. Veterinary Journal of Ankara University. 62: 51-55. https//doi:/10.1501/Vetfak_0000002657.

Singh, A.K., Kumar, A., Honparkhe, M., Kaur, S., Kaur, H., Ghuman, S.P.S., Brar, P.S. (2018). Comparison of in vitro and in vivo fertilizing potential of buffalo bull semen frozen in egg yolk, soya bean lecithin-and liposome-based extenders. Reproduction in Domestic Animals, 53: 195-202. https//doi:/10.1111/rda.13092.

Singh, R.K., Kumaresan, A., Mir, M.A., Kumar, P., Chhillar, S., Tripathi, U.K., Mohanty, T.K. (2017). Computer assisted sperm analysis: Relationship between the movement characteristics of buffalo spermatozoa and sire fertility. Indian Journal of Animal Research, 51: 660-664.

Soysal, M., Ozkan, E., Kok, S., Occidente, M., Tuna, Y.T., Gurcan, E.K., Matassino, D. (2007). Genetic characterization of indigenous anatolian water buffalo breed using microsatellite dna markers. Italian Journal of Animal Science. 6: 409-412. https//doi.org/10.4081/ijas.2007.s2.409.

Soysal, M., Ünal, E., Gürcan, E. (2020). Conservation and sustainable use of farm animal genetic resource. Journal of Animal Science and Products. 3: 210-227.

Şahin, D., Baştan, I., Çil, B., Tekin, K., Akçay, E., Daskın, A., Stelletta, C. (2020). The number of false mounting affects the quality of semen in bulls. Livestock Studies. 60: 9-14. https//doi:/10.46897/lahaed.701388.

Tuncer, P.B., Bucak, M.N., Büyükleblebici, S., Sarı̈zkan, S., Yeni, D., Eken, A., Gündoğan, M. (2010). The effect of cysteine and glutathione on sperm and oxidative stress parameters of post-thawed bull semen. Cryobiology. 61: 303-307. https//doi.org/10.1016/j.cryobiol.2010.09.009.

Vincent, P., Underwood, S.L., Dolbec, C., Bouchard, N., Kroetsch, T., Blondin, P. (2018). Bovine semen quality control in artificial insemination centers. Animal Reproduction. 9: 153-165

Yeni, D., Avdatek, F. (2017). Effect of carnosic acid on the short term storage anatolian buffalo epididymal sperm. Kocatepe Veterinary Journal. 10: 187-195. https//doi:10.5578/kvj.58659.

Yılmaz, S. (2013). Water buffalo breeding in Afyonkarahisar province; sample of Küçükçobanli Village. M.Sc. Adnan Menderes University, Aydın, Turkey. 